\title{
The Identity of Brand with its Influenceable Character on Client Choices of Predominant Restaurants Accra as the Lens
}

Aphu Elvis Selase ${ }^{1 *}$, Abdoulaye $\mathrm{AM}^{2}$, Mawuli MD ${ }^{3}$ and Brantson TE ${ }^{4}$

${ }^{1}$ College of Public Administration, Huazhong University of Science and Technology, Wuhan, Hubei, China

${ }^{2}$ China University of Geosciences, Wuhan, Hubei Province

${ }^{3}$ Kwame Nkrumah University of Science and Technology, Kumasi, Ghana

${ }^{4}$ School of Energy Resources, China University of Geosciences, China

\begin{abstract}
The key resource of any business is all around perceived brand that theoretically impact item or administration decision over contenders mark or brand. This social resource is a major and focal idea in the advertising of items and administrations particularly in promoting indigenous eateries (restaurants). Building steadfastness by means of interests in brand value would then give one mode to perceiving the estimation of current clients, and the significance of giving proceeding with administration to them so as to hold them at bay. The general target of this exploration was to research how brand personality (equity) of indigenous restaurants impacts client decision(s). The examination was directed on forty five (45) respondents, containing staff and clients of indigenous restaurants in Accra Business Centre. The specialists utilized non-probability examining (Purposive Sampling) in testing out the respondents. The examination results were broken down by utilizing SPSS and Microsoft Excel programming. The outcomes from the examination uncovered that on the diverse measurements of administration quality there are holes between client's desires and impression of the considerable number of factors researched on. This means that the customers are not fully satisfied about the service quality at indigenous restaurants in Accra Business Centre most are not aware about brand quality and equity that major components in indigenous restaurants operation. Despite the fact that it could be inferred that indigenous restaurants in Accra Business Centre had to some degree utilized branding practices and offer support of their best of capacity, the specialists trust significantly more should be done and gave the accompanying proposals. That the indigenous restaurants in Accra Business Centre should discover inventive methods for separating themselves from others, find innovative methods for imparting their indigenous eateries mark, prepare administration cum workers and in addition teaching them on marking hones. Clients by and large need instruction on brand and brand components and standard administration components accessible in the hospitality industry. These will empower them request better administrations and have their necessities met.
\end{abstract}

Keywords: Brand; Business; Client; Choices; Indigenous; Identity; Influence; Restaurants

\section{Background}

One of the most powerful tools that organizations use is branding towards differentiating themselves, their products and services from those of their competitors. According to Kotler and Keller, a brand is a name, design, symbol or major feature that helps to identify one or more products or services from a business or organization. The reason for branding being powerful is that the moment a consumer recognizes a brand it provides a lot of information such as identity, value, some unique features of the branded product or service to that consumer. This helps them to make quicker and better decisions about what products or services to buy. The hospitality industry in Ghana is engulfed with intense competition which should be a concern of great importance for companies to ascertain the right knowledge and offer quality service to customers through efficient branding strategies.

As hotel and companies fine-tune their identities, reposition their products and services to promote growth through aggressive competitive strategies, owners and operators are frequently quite indecisive about how to apply a brand strategy to the marketing of their product. Companies within this industry stand significant benefits of building a strong hotel brand to help them strategically differentiate themselves in the minds of the customers and gain a competitive advantage. Forgcas suggest that branded hotels outperform nonbranded properties on performance indicators such as average price and return on investment. Brand name plays an important role in the branding strategy of organizations. The brand name is the name that communicates the identity of a brand from other brands. Normally it is that part of a brand that can be vocalized or pronounced. According to Berry [1] service branding is seen as the corner stone of service marketing in the $21^{\text {st }}$ century. This is because of the inherent service characteristics (i.e. inseparability, heterogeneity, tangibility and perishability). In another development the importance that people or customers attach to these brands in deciding which brand to buy is very important for people in the field of business and marketing. However, the most important factors consumers consider when choosing indigenous restaurants is food quality, service, value, cleanliness, comfort, and entertainment.

Service quality on the other hand is linked to the concepts of perceptions and expectations. Customers' perceptions of service quality result from a comparison of their before-service expectations with their actual service experience. The service will be considered excellent, if perceptions exceed expectations; it will be regarded as

*Corresponding author: Aphu Elvis Selase, College of Public Administration, Huazhong University of Science and Technology, Wuhan, Hubei, China, Tel +8617396874660; E-mail: elvis.qapito@yahoo.com

Received September 28, 2018; Accepted December 10, 2018; Published December 20, 2018

Citation: Selase AE, Abdoulaye AM, Mawuli MD, Brantson TE (2018) The Identity of Brand with its Influenceable Character on Client Choices of Predominan Restaurants Accra as the Lens. J Account Mark 7: 302. doi: 10.4172/2168 9601.1000302

Copyright: ( $) 2018$ Selase AE, et al. This is an open-access article distributed under the terms of the Creative Commons Attribution License, which permits unrestricted use, distribution, and reproduction in any medium, provided the original author and source are credited. 
good or adequate, if it only equals the expectations; the service will be classed as bad, poor or deficient, if it does not meet them. The relationship established between branding and service quality is high, for example in the case of McDonalds, Burger King, and Carl's Junior, noted international fast food service providers have fulfilled the need for convenience for the customers. The service industry in Ghana, especially the hospitality industry is noted for yearly growth as a result of economic and political stability, resulting in business expansion and the promotion of investment opportunities. Satisfying customers is one key area separating or distinguishing the various companies in this business. Businesses should recognize that keeping current customers is more profitable than having to win new ones to replace those lost.

Brand personality is a one of a kind arrangement of brand affiliations inferring a guarantee to clients. It incorporates a centre and broadened character. Centre character is the focal, ageless embodiment of the brand that remaining parts consistent as the brand moves to new markets and new items. Centre character comprehensively centres around item properties, benefit, client profile, store climate and item execution Extended character is woven around mark personality components composed into durable and significant gatherings that give mark surface and culmination, and spotlights on brand identity, relationship, and solid image of affiliation. Keeping in mind the end goal to be viable, a brand personality needs to reverberate with clients, separate the brand from contenders, and speak to what the association or organization can and will do after some time [2]. Brand way of life according to Gylline and Lindberg-Repo is characterized as an arrangement of brand affiliating the advertisers are planning to make and acquire [3]. Brand character and brand picture are connected yet particular idea as both are basic elements of solid brand [4].

Vytautas recommended that Brand Identity began from before activity of a brand consequently, comprehension of brand personality connotes that state of mind towards mark is being changed. Significance of brand in the market is impacted by organization's capacity to assess the reality how shopper translates the picture of brand and friends' capacity to deal with the brand procedure [5]. Positive picture is worked through passing on mark character to shopper effectively. Brand steadfastness can be made and kept up by solid character picture linkage. Brands in the field of mass-advertising began in the nineteenth century with the coming of bundled merchandise. Industrialization moved the generation of numerous family unit things, for example, cleanser, from nearby networks to incorporate manufacturing plants. When sending their things, the plants would actually mark their logo or symbol on the barrels utilized, broadening the importance of "mark" to that of a trademark.

\section{Statement of the problem}

The indigenous restaurant operations in Accra have been competitive over the years and from a casual observation can be said to be growing significantly. The industry comprises of way side petty food venders, typical localized eateries commonly referred to as "Chop Bars" and well-structured formal restaurants but offer purely indigenous menu. These restaurants have adopted brand identities that make them stand out from their peers and these identities have become accepted references by customers who demand value added food products and services to satisfy their need and wants and also meets the expectations being communicated through the brand identity. Consumer behaviour in the indigenous restaurant operation is becoming increasingly unpredictable and more fragmented. Although, the development of food related products and the provision of quality services is crucial for these restaurants their ability to meet and sustain customer demand is becoming a huge challenge as constraint of finance, efficient management of the facility, recruitment of more appropriate human resource, and the need for continuous upgrade in services offers stares them right in the face. These restaurants are not isolated from the competitive environment where the big guys-international restaurant chains, and local one that have up their game to march up with this foreign chains. The competitive environment is characterized by fierce innovative service offers, modernized and attractive infrastructure and sometime introduction of technology [6]. In many instances most literature explains branding only as a product element with less focus on the brand identity of the company. Most Ghanaian restaurants have identified themselves with names that customers have ascribed to even though some names do not have any clear meaning except to communicate the owners of the company. This restaurant also fall in the same pool, for instance brands like Agbaamami, Odorice, Las Palmas, Berima Nkwae etc. are noted facilities patronized by all shades of persons without any class discrimination. The questions that quickly comes to mind includes: what informed the choices of that brand identity; what do such brand names seek to communicate; do such brand identities influence the target customers and to what extent does the brand identity make such restaurants competitive.

To find out how the brand identity of indigenous restaurants in Accra Business Centre influences customer choices, the specific objectives of the research are as follows: To find out customer's awareness of the components of brand identity, to find out the influence brand identity has on customers' choice on local restaurants, to find out if the components of brand identity adopted by these restaurants meet the standard required and to ascertain how brand identity benefit these restaurants. Are customers aware of the components of brand identity? How has brand identity influence customers' choice of local restaurant? Do the brand identities of these restaurants meet the standard component required? How does brand identity benefits these restaurants? The above questions are not left out of oblivion in as much as this study is mirrored.

Significantly, the research work will be relevant to the hospitality industry by assisting starters and existing local restaurants with the use of branding in promoting their organizations, services and products. The research information will also be relevant to academia for further academic explorations. As the scope will have it, the dependent and independent variables for consideration by the research are branding and customer choice. Branding is the independent variable and customer choice being the dependent variable. Furthermore, under the branding, issues of brand equity such as brand awareness, brand loyalty; brand identity will be explored theoretically whereas issues of perceived quality through courtesy, friendliness, approachability, trustworthiness, on the part of service providers will be explored under service quality. The research will be conducted in the Accra metropolis, with selected restaurants within the hospitality industry in Ghana.

\section{A brief profile of the study area}

The focus of the study was $\mathrm{n}$ on indigenous restaurants in Accra Business Centre of Ghana. Accra Business Centre is one of economic zone in Accra, Ghana where various institutions such as banks, and myriad of traders and various offices are strategically located. The area is densely populated especially on week days where people from all works of life trade their businesses. Hence setting up restaurants around the area has the potential of bringing profitable returns to various restaurants as more workers take their lunch during afternoon breaks. 


\section{Review of Literature}

\section{Concept of branding-definitions}

'Brand' is this manuscript's central construct and so will be discussed before service quality, identity and brand performance. This section of the review considers brand from input, output and evolutionary perspectives [7]. An 'integrated' definition of brand is then forwarded which augments key elements from definitions that have been reviewed. An overview of corporate branding then follows given its pervasiveness in the service sector.

Defining brand: There are shifted elucidations of brand in both the writing [8] plot how one of the biggest regions of contradiction between specialists, incomprehensibly, identifies with characterizing brand. Be that as it may, given the focal significance of brand to this venture, it is essential to build up a reasonable comprehension of what a brand is. De Chernatony and Riley recognize nine brand topics under three points of view (info, yield and transformative) to characterize perspectives with respect to mark. This scientific categorization will be utilized as a system to present perspectives on mark as appeared in Table 1.

In the light of an 'informative' viewpoint, a brand is conceptualized as something the advertiser makes where the brand is: a lawful instrument (e.g. (') $)$; a logo; an organization (e.g. English Airways) or any more all-encompassing personality framework regarding how the association needs to be seen by buyers. The American Marketing Association previously distributed a brand definition in the 1960s which thought about a brand as "a name, term, sign, image, or plan, or a mix of them, expected to recognize the merchandise or administrations of one vender or gathering of dealers and to separate them from those of contenders". The latest AMA definition draws intensely on this definition where a brand is: "a name, term, plan, image, or whatever other element that distinguishes one dealer's great or administration as particular from those of different merchants. The lawful term for mark is trademark. A brand may distinguish one thing, a group of things, or all things of that vender. Whenever utilized for the firm all in all, the favoured term is exchange name" [9].

This definition has been scrutinized for being merchandise driven, this case is far from being obviously true given it unequivocally thinks about the two products and enterprises, while different components of the definition, for example, name, outline, image or trademark have parallel pertinence to benefit brands. Be that as it may, it could be fought the AMA's definition overemphasizes obvious indications of brand to the detriment of customer(s) or partners. Kotler and Keller, likewise characterized branding as a strategy by which relatively comparable items are separated from each other. Brands are characterized as a name, term, sign, image or outline or a blend of these proposed to distinguish the merchandise or administrations or one vender or gathering of merchants and separate them from those of contenders (competitors). Brand names fluctuate in the measure of intensity they have in the commercial centre.

At one outrageous are brands with a genuinely high level of purchaser mark mindfulness. Still different brands appreciate mark

\begin{tabular}{|c|c|c|}
\hline Input Perspective & Output Perspective & Evolutionary Perspective \\
\hline Legal instrument & Image & Image Evolving entity \\
\hline Logo Personality & Personality & \\
\hline Company & Relationship & \\
\hline Identity & Adding value & \\
\hline
\end{tabular}

Table 1: Taxonomy for brand perspectives. inclination - purchasers select them over others. Some brand names order a high level of brand devotion. A ground-breaking brand name has a high level of brand value. Kotler and Keller, additionally focused on that, a great name can add enormously to an item achievement. Finding a decent brand name is a troublesome errand. It starts with a cautious survey of the item and its advantages, the objective market, and proposed showcasing procedures. Alluring characteristics for a brand name incorporate these:

- It should suggest something about the product/service benefits and qualities.

- It should be easy to pronounce, recognize and remember.

- The brand name should be distinctive.

- The name should translate easily into foreign languages.

- It should be capable of registration and legal protection.

The demonstration of branding is basically connected with distinguishing proof of people offering in the generation of merchandise and ventures to encourage proprietors and purchasers from vulnerabilities in choosing a specific brand. Ward [10] additionally sketched out that brands can be based either around items/ administrations or around clients. They are considered before item drove or client drove procedures. On the off chance that an advertising technique in light of brands is to be investor esteem upgrading, the brand must empower the business to procure super benefit on its substantial resources, subsequently the brand turns into an elusive resource of the business. It could likewise be contended the AMA point of view neglects to represent the ground-breaking job feeling plays in mark advancement. Other researchers' work takes after the AMA's position. For example, Farquhar characterizes a brand as "a name, term, outline or check that improves the estimation of an item past its practical reason" (p.25). Likewise, Aaker, 1996a [11] thinks about a brand as: "a name, term, sign, image, or outline, or blend of them which is proposed to recognize the products and enterprises of one merchant or gatherings of dealers and to separate them from those of contenders." The reason being, while a name, term, image et cetera assume an essential job in mark improvement they could be viewed as physical appearances of the enthusiastic security brands hope to create with the last being prominently more critical than the previous.

In a comparative way, Doyle thinks about brand as a particular name, image or outline which is utilized to separate a specific item regarding useful needs yet in addition mental necessities e.g. status. While Doyle's see features the mental measurement of brand, considering the development just as a name, logo or other outward images. Kotler tosses his weight behind the statements of Doyle. Martineau opine that a 'yield' point of view a brand is considered as existing in the buyers' psyches, shaping a picture which sets connection among clients and the brand. It has been contended that connections frame an inexorably critical piece of advertising's predominant 'rationale' [12]. In this rationale, brands are exemplified and buyers frame organizations with the brand as though the brands were people $[13,14]$. A few creators think about brand with regards to a relationship [15,16] while with regards to building brand personality, Aaker considers connections as "the main issue". In this sense brands are believed to go up against the type of a mental and verifiable agreement between the brand proprietor and purchaser through which shared desires are set and (to differing degrees) met. Fournier contends for the importance of expanding relational connections into the brand area where brandpurchaser connections comprise of features, for example, love, duty 
and association while Agarwal (2004) [17,18] noticed how standards of appraisal utilized in close to home connections reach out to judgments about brands.

The reason brands are lifeless thus can't think or feel as people do [19] contending components of a human relationship, for example, the response of feelings, for example, love are "subjectively extraordinary" for brands and people (). Drawing on crafted by Shultz and Shultz, who take note of how brands bring a purchaser and dealer together, Veloutsou and Moutinho allude to mark connections with regards to a bond, be it monetary, physical or passionate, which may speak to more proper dialect. The significance of this point of view has additionally been increased by the developing job of corporate social obligation where more extensive partner administration is vital. Henceforth, the yield point of view makes it unmistakable a brand is in excess of a logo, name or image while the idea of an 'agreement' or semi contract offers ascend to common desires being shaped between the brand/ association and its partners with regards to a relationship that might be all the more fittingly conceptualized as an 'association' or 'security'. At last, more transformative viewpoints on mark "see marks as advancing from a contribution to a yield point of view" [20]. Following Goodyear, Kunde, noticed how marks are not static but rather advance after some time. In this sense marking moves from being something the brand proprietor does to the customer to something the purchaser does with the brand [21]. This position is steady with Holt who contends customers regard marks as a social asset, inside a "dynamic persuasive relationship" (p. 80), which liberates them from the control or mastery of brand interchanges.

Further, de Chernatony and Riley broadened their writing audit of 1997 by considering a brand additionally as a shorthand gadget that encourages the review of brand profits by memory, a hazard reducer with expanding brand nature and as esteem frameworks, that is a framework or "group of" values which speaks to the brand. Such increases can be considered as 'input' elucidations of brand (i.e. something the advertiser makes). Developing de Chernatony and Riley's [22] work, de Chernatony additionally considered brands regarding situation so the brand is quickly connected with a specific advantage in connection to its rivals and a dream which gives mark bearing, centre and reason. At last, seeing a brand as a personality framework was currently alluded to a brand as a bunch of qualities. The last can be viewed as all the more a clear as crystal title than de Chernatony and Riley's work. The view that brands are worried about qualities has been vital to de Chernatony's (and co-creators') work. Afresh, de Chernatony considers esteems as being fundamental to characterizing brand where "a fruitful brand is an identifiable item, administration, individual or place, expanded in, for example, way that the purchaser or client sees pertinent, one of a kind, reasonable included qualities which coordinate their needs generally nearly." [23]. This is reliable with de Chernatony's later work where a brand is characterized as "a bunch of qualities that empowers a guarantee to be made about a novel and invited understanding". Subsequently, it very well may be perceived how esteems shape an essential job of de Chernatony's conceptualization of brand. In perspective of the former segment, it turns out to be clear different points of view on mark exist. Be that as it may, it could be contended that, to date, an incorporated and allencompassing perspective of brand still can't seem to be produced that catches the breath of build as delineated previously.

In light of this survey of the brand writing it is currently proper to build up an incorporated view or meaning of brand. Such a methodology means to increase the different positions sketched out above. Subsequently, brands can be considered as: a build that assists with the conveyance of brand-related guarantees made by the merchant/organization to its partners; encouraging the development of a commonly advantageous and advancing bond between the vender/ enterprise its partners; being guided by utilitarian and an enthusiastic component. Joining these focuses prompts an 'incorporated' meaning of brand where a brand is a develop that conveys showcasing guarantees to encourage the arrangement of a commonly useful and advancing security between the vender (and organization) and its partners in view of useful and passionate qualities [24].

Consequently, this definition can be seen as an attempt to augment several views outlined above. The definition has been conceptualized in Figure 1, where brand is developed as part of a brand-stakeholder process (Holt, 2002) and so is couched within the evolutionary school.

Brand identity: A few brand advertising scholastics have added to the brand character writing [25] whose applied structures will be audited later in this section. In any case, it is imperative to consider how these creators' characterize image personality for a few reasons. Drawing on crafted by Hatch and Shultz [26], de Chernatony, considers mark way of life as "the particular or focal thought of a brand and how the brand imparts this plan to its partners". By thinking about partners, de Chernatony's work has the advantage of taking a vital viewpoint and being especially important to benefit brands. In any case, this definition looks somewhat like Hatch and Shultz's corporate character definition which in itself has been dominatingly educated by visual personality researchers, for example, Margulies and Olins [27]. While considering brand character Kapferer characterizes the billed as "determining the aspects of the brands' uniqueness and esteem". While this definition urges mark advertisers to consider building up an unmistakable brand personality, what establishes 'uniqueness' or 'esteem' could be thought about to some degree dynamic. Seemingly, these outcomes in a definition that is trying to get it.

Aaker views mark way of life as "what the association needs the brand to remain for in the client's psyche" or "how strategists need the brand to be seen". Aaker's work raises a few focuses. To begin with, mark character radiates from the 'association'. It's anything but a purchaser or customer side develop (mark picture). Second, inside the association, the "strategist" plays a critical brand personality job. While it isn't totally clear who this individual is, one would expect the strategist holds a senior position inside the association, for example, the Marketing Director or Marketing Vice President [28]. The reason being this individual is at last in charge of executing authoritative technique of which mark personality has an essential impact. Third, mark character is visionary, [i.e. the brand] needs to offer" [29]. Correspondingly, Joachimsthaler and Aaker see mark way of life as the "vision of how that brand ought to be seen by its intended interest group" or all the more concisely as "what the association needs the brand to remain for". This infers the organization should settle on its own decision for what it needs to rely on [30]. In any case, a few issues emerge from Aaker and Joachimsthaler's definition. For instance, these creators allude to a "dream" however don't expand on whose vision

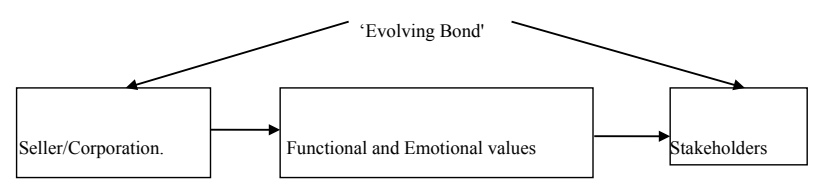

Figure 1: Conceptualizing a definition of brand-an integrated perspective. 
this really is. This is an advantage of Aaker's work insofar the vision lies with the "strategist".

In accordance with different researchers [31], Keller and Kotler make the refinement between mark personality and brand picture: "Character is the manner in which an organization expects to recognize or position itself or its item. Picture is the manner in which general society really sees them. For the correct picture to be set up in the brains of customers, the advertiser must pass on mark character through each accessible correspondence vehicle and brand contact. Personality ought to be diffused in promotions, yearly reports, pamphlets, inventories, bundling, organization stationery, and business cards. On the off chance that "MTN implies benefit," this message must be communicated in images, hues and trademarks, environment, occasions, and worker conduct." This view echoes Keller who takes note of "a picture is the means by which you are seen, and a character is the manner by which you seek to be seen". Consequently, it very well may be perceived how Keller and Keller and Kotler's work help separate the build as well as obviously lines up with different researchers where mark personality is considered as radiating from the association $[32,33]$. In view of the above, Aaker and Aaker and Joachimsthaler's [6] work was viewed as an especially helpful beginning stage for building up a fundamental administration mark personality definition. This rationale was principally guided by the reasonable, succinct and unambiguous dialect these researchers utilize which determines the 'space' of the develop [34]. Besides, therefore, guided by this justification and these creators' work, benefit mark character is to begin with characterized as: The strategist's vision of how an administration brand ought to be seen by its partners.

Brand Equity-building strong brands: Since the presentation of the idea in the 1980s [35], a scope of meanings of brand value have risen that mirror a few unique purposes. While a considerable lot of these definitions have concentrated on the idea of the brand as a benefit, this has to a great extent been inside a products driven rationale as opposed to an administration driven rationale. For instance, Keller characterizes mark value as 'the differential impact of brand learning on the purchaser reaction to the showcasing of the brand'. A solid brand is made by giving the brand an identity that individuals can relate to as per [36]. For instance, Papaye mark is said to have an innovative identity, which its clients can relate to. This creator goes on further to state that there is not at all like brand steadfastness, rather, a firm should try to manufacture a brand that is desirable over different brands.

Conversely a straightforward yet quick definition that envelops the two products and administration driven perspectives is given by Ambler: 'what we bear in our heads about the brand'. In giving this definition Ambler perceives that there are likewise essential segments of the aggregate brand resource in the psyches of representatives, investors and different partners in the promoting framework.

The most recent five years a surge of research about brands in benefit connections has broadened Berry's benefit mark value display. The exploration has given further applied and exact understanding about the job of administration marks as 'social resources' and how these benefits make budgetary incentive for associations. The hole in Beckwith's book is that he neglects to recognize the impact that solid mindfulness has on mark value. In Ghana, mindfulness includes a ton fabricating a solid distinction. For instance, in Ghana, MTN does not really give the best correspondence benefit, but rather it has figured out how to manufacture a solid brand by making huge mindfulness in the Ghanaian market. Likewise, as much as the specialists concurs with the vast majority of Beckwith's contentions on marking, they can't help contradicting his attestation that it is reasonable to leave customers who may have risked upon the firm through the business catalog since they can never be faithful to the brand. This difference depends on the conviction that even such customers can be transformed into faithful ones by building solid associations with them.

\section{Branding of hospitality industry in Ghana}

Akotia and Ofori, have done some research work in the area of branding in Ghana but solely on nation branding or country branding. Other studies on hotels in Ghana were only particular about environmental practices of hotels in Ghana [37] and tourism development. However, the researchers found little studies done on branding of indigenous restaurants in Ghana, and this is the gap the researchers sought to fill in this particular research. Essentially, a review of the literature has shown that there are accepted general branding practices, as well as a framework for services branding. Documentations by Kotler \& Keller, Ward were examined and served as the main framework or guide underlying issues on branding. In addition, Brodie's framework on relational branding as supported by Gummesson and Kapfereer were also examined. Berry, Holverson \& Ravez' pages' were very helpful in pointing out the benefits in branding. Berry, Roger A. Karin, Steven W. Hartley \& William Rudelius pages' was useful in identifying the major differences between services and products. Similarities between service brand and relationship marketing and their importance were amplified in the pages' of Gronroos, Riley, de Chernatony and Little. However the SERVQUALs dimensions of Parasuraman served as the basis for the review of literature on service quality.

Unfortunately, a gap found in most of the literature is that they were not placed in the Ghanaian context. Thus, in conducting this study, a combination of the various literatures reviewed will be applied to the Ghanaian context and this will serve as the theoretical framework for determining whether indigenous restaurants in Accra Business Centre are engaging in branding practices or not. The next chapter looks at the methodology of the research. This shows how primary data was collected from customers of indigenous restaurants in Accra Business Centre. Hence, we can infer that both branding and perceive service quality has a direct and indirect influence on loyalty, whereby the indirect influence of service quality is mediated by perception towards the restaurants (corporate) image. The importance of the brand as the fundamental asset of any business is well recognized by managers, consultants and business writers [38].

We have contended both adroitly and by utilizing experimental proof that 'the administration mark' in its job as a social resource is a crucial and focal idea in the showcasing of items and administrations. The North American scholastics including Berry, Prahalad and Srivastava, and European scholastics including Riley and de Chernatony and Balmer are giving the energy to this improvement [39].

Conceptual view of branding for services: This examination will offer a theoretical outline of marking and brand value and their specific significance inside an administration setting. Marking and brand value writing is inspected and considered in connection to administrations showcasing. Taking everything into account, the examination looks at the vital significance of marking and brand value to administrations advertisers, and how administrators can make utilization of these instruments practically speaking.

\section{Brand equity}

Albeit no accord exists on a particular, one of a kind definition, 
mark value is regularly characterized in correspondence with Aaker's conceptualization of an arrangement of brand resources and liabilities connected to a brand, its name and image, that include or subtract from the esteem given by an item to a firm or potentially that company's clients" (p. 15). So also, Keller sees mark value as "the differential impact of brand learning on customer reaction to the showcasing of the brand. Farquhar all the more quickly characterizes mark value as the esteem that a brand name adds to an item. Specifically, purchasers appear to pay a value premium for better-known brand items with tantamount quality levels as non-premium estimated lesser-known brand items, because of the apparent esteem credited to the brand name [40]. Thus, mark value is an imperative promoting develops from a budgetary, vital, and buyer conduct point of view.

Brand equity and services: Because of their tendency, administrations buys might be harder to choose and assess. Customers acquiring merchandise may utilize one or some blend of the accompanying criteria to assess buy choices, including the different prompts of style, shading, mark, feel, bundle, mark name, and value [41]. Cost and the physical condition encompassing the administration have been viewed as the essential quality signals accessible to the customer [41]. This task proposes mark value may likewise assume a noteworthy job in assessing quality, especially without coordinate involvement in that item classification. 'Brands' work as a hazard reducer might be much more imperative since quality might be hard to decide before buy, or even post-buy [42]. Due to their experiential and trustworthiness properties, benefit experiences might be more impacted by extraneous signals, for example, brands [43]. A case of missing data and brands as methods for hazard decrease can be found in the accompanying situation. A purchaser is looking for movement data - picking a goal, choosing an aircraft, or booking lodging yet has practically zero past involvement in this item classification. Wishing to limit their hazard they select American Express' movement benefits because of the positive meanings the brand name summons and the attributes regularly connected with it (experience, selectiveness, high caliber) may likewise fill in as a way to expand the buyer's judgments of saw esteem, fulfillment, and quality [44], accordingly cultivating recurrent buy conduct, positive informal expectations, and going about as a support for benefit disappointments. This affirmation is steady with Gronroos' model of administration quality, wherein picture is depicted as a quality measurement customers will use to evaluate benefit quality, regardless of whether their fleeting knowledge repudiates their long haul picture appraisal (e.g., a lodging the purchaser accepts to be esteemed loses his/her reservation, has no watchmen accessible to convey gear to the room, can't suit smoking inclination, and so on, may in any case hold a positive in general picture in the buyer's psyche giving poor people encounter isn't rehashed on consequent events).

Thus, mark value may likewise assume a critical job in administrations showcasing because of its effect on recuperation from benefit disappointments (or even as a methods for thwarting the customer's recognition that a disappointment happened). Cultivating positive brand value could incite the customer to respond less contrarily to benefit disappointments since a poor administration experience would be conflicting with their already held state of mind in regards to the estimation of the brand name. Powerful utilization of brand value offers benefit advertisers one road for upgrading the underlying choice likelihood, creating devotion, holding clients, and supporting connections [45], by going about as a hazard reducer. Since shoppers have neither one of the infinites time allocated, nor inspiration/capacity, to altogether contrast items earlier with buy, they are probably going to utilize heuristics to gauge item quality among contending brands. Therefore, shoppers expect changing degrees of hazard when they purchase items. Brooker recommends that when shoppers purchase a brand with which they are natural, they trust the hazard to be not exactly for buys including another brand or new item classification. Items with moderately abnormal amounts of brand value are believed to be favored by shoppers to relieve the danger of making a poor choice, wherein brands go about as a sign for foreordaining quality.

Financial matters based research demonstrates that the more particular a quality sign, the more valuable it is as an indicant of value [45]. Brand names are very particular signs, since no other firm or just a couple of items inside an aggressive line of items share them. For administrations buys when all is said in done, the measure of apparent hazard is more prominent than for merchandise. All things considered, the requirement for extra quality signals would appear to be especially significant to administrations specialist. Under these conditions, benefit mark names should work effectively as quality-sign data. Zeithaml points out that in light of the fact that more serious dangers, expenses, and absence of information concerning choices may go with the buy of administrations, buyers might be more brand steadfast with administrations than with products. Given that people have a tendency to be inherently chance aversive and that administrations are seen to be more dangerous buys, more elevated amounts of brand fondness ought not to be astonishing [46]. Furthermore, Bharadwaj propose that "When purchasers can't undoubtedly assess the capacities of the specialist co-op and the quality and estimation of the administration gave, mark notoriety fills in as a vital intermediary for quality and other key purchasing criteria that can't be effortlessly assessed". A standout amongst the most profitable assets a business has is the notoriety of its brands [47].

Notwithstanding recognizing one market offering from another, purchasers frequently utilize mark names as a heuristic to demonstrate the item's quality or unwavering quality [48]. This might be especially valid for buys where the shopper has practically zero involvement in that because of the impalpable idea of administrations, developing a solid picture or brand distinguishing proof would appear to be much more basic for administrations than for merchandise. Cultivating positive brand value could incite the buyer to respond less adversely to benefit disappointments. Since poor administration would be conflicting with their already held state of mind in regards to the estimation of the brand name. Building steadfastness by means of interests in mark value would then give one mode to perceiving the estimation of current clients, and the significance of giving proceeding with administration to them so as to hold them.

\section{The influence of brand identity on customer choice of indigenous restaurant}

There is gigantic expansion of eatery marks in Ghana and over the globe because of which eateries administration confronted challenges to assemble a one of a kind brand picture in purchasers' brain. In the light of brand picture is one of the key parts that empower inns to increase better favourable position over their opponents, the fundamental point of this exploration was than discover what benefit quality measurements can advance brand picture of eateries in Ghana. Eateries clients' study reactions investigated uncovered that sympathy, responsiveness and dependability discernments saw confirmation and physical assets, and in addition the $7 \mathrm{ps}$ were instrumental in sustaining eateries mark picture.

An exceptionally fascinating investigation of Opoku and Hultman, 
kept up the thought that notwithstanding marking is itself totally the way toward making and building a brand picture. What's more, as indicated by them, 'making a brand picture means' an exertion that "connects with the hearts and psyches of clients". Gronroos underscored the extraordinary significance of brand picture for benefit firms since when the clients utilize benefit; they see the firm and its assets by their judgment of the association among them and their specialist co-ops. His discoveries portrayed that the clients define picture as they see the segments of the firm and build up their discernments. As indicated by results, it tends to be reasoned that just sympathy, responsiveness and unwavering quality discernments were drivers to building lodging brand picture. Strikingly, saw affirmation and physical assets did not contribute anything critical in sustaining brand picture. A standout amongst the most profitable assets a business has is the notoriety of its brands. Notwithstanding recognizing one market offering from another, purchasers regularly utilize mark names as a heuristic to demonstrate the item's quality or unwavering quality [49].

Customer's perspective of service quality-servqual model: This model depends on the premises by which clients can assess an association's administration quality through looking at their impression of its administration and with their very own desires. SERVQUAL is viewed as a non-specific estimation device that can be connected over a wide range of administration enterprises. Parasuraman says that in administration and retail business, SERVQUAL is a multi-thing scale which is produced to survey client impression of administration quality yet initially it is created shape GAP display. The creator likewise contends that SERVQUAL must be dependably evaluated and estimated keeping in mind the end goal to enhance administrations quality. He specified that SERVQUAL is a vital model to recognize the holes between client desires for the administration and their impression of the real execution of the administration.

Figure 2: The SERQUAL scale. It depends on a whole show by Parasuraman [1]. The creators showed that "In benefit writing the hole demonstrate is the most solid and has the most significant commitments". The model accentuation four key inner holes identifying with administrative view of administration quality, and assignments which is associated with benefit conveyance to clients. Both the real form of SERVQUAL and its changed varian created five measurements of administration quality like effects, dependability, responsiveness, affirmation, and sympathy. Zeithaml, Berry and

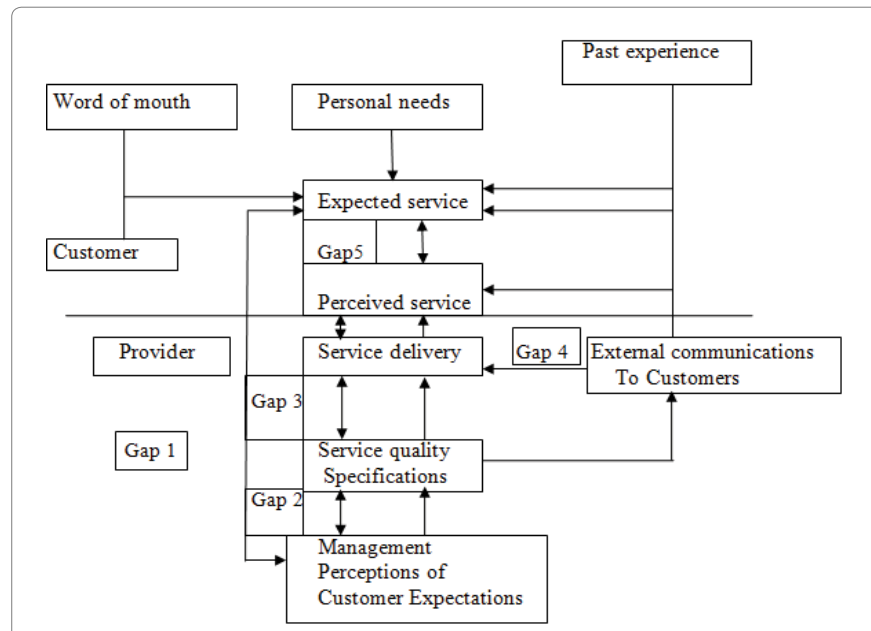

Figure 2: The SERQUAL scale it depends on a whole show by Parasuraman et al.
Parasuraman distinguished 10 criteria utilized by customers in assessing administration quality. In subsequence investigate they found a high level of relationship between's few of these factors thus united them into five wide measurements [1].

These creators depict that effects are about the physical offices, hardware, and appearance of individual and nearness of clients and it is additionally imperative for making a decent climate. This measurement part of an administration is one of only a handful couple of measurements that a potential specialist co-op can know and assess ahead of time of investment. Unwavering quality implies that the administration organization must have the capacity to play out the guaranteed benefit constantly and precisely. It additionally makes association's limited time exertion which can add to member desires. By and large, execution at the most astounding standard is essential to dependability. Responsiveness alludes to the readiness to encourage members and give incite mindfulness. The clients anticipate that their demand will be explained rapidly and superbly. Affirmation implies that the clients need to depend on considerate and proficient representatives who pass on trust and certainty. The last measurement sympathy is related with minding individual that deals with clients. Compassion likewise demonstrates great comprehension of the client's needs and needs. Zeithaml specify that Assurance and Empathy contain things that are speaking to seven unique measurements; (Communication, validity, security, capability, politeness, understanding/knowing clients, and access). They didn't stay particular all through the few refinements throughout the years which prompted the expanded administration quality model. Zeithaml said that the reason for SERVQUAL is to fill in as an analytic instrument for recognizing an association's administration quality shortcoming and qualities which is revealed for marking impact and brand personality on client decisions of indigenous eateries.

\section{Components of brand identity}

Creating a strong brand also includes: understanding customer needs, exceeding customer expectations on quality, overall cost leadership and efficient brand positioning. This framework distinguishes between three marketing processes:

- making promises (external marketing between the organization and customers);

- enabling and facilitating promises (internal marketing between the organization and people working in the organization/ network); and

- Keeping and supporting promises (the interactive marketing between people working within the organization/network and end customers).

All the more as of late Grönroos inserted these three procedures in his meaning of advertising, consequently characterized Marketing as a client centre that saturates hierarchical capacities and forms and is adapted towards making guarantees through incentives, empowering the satisfaction of desires made by such guarantees and satisfying such desires through help to clients' esteem producing forms, along these lines supporting worth creation in the association's and also its clients' and other partners' procedures. Research by Riley and de Chernatony distinguished the calculated likenesses between the expansive thoughts of 'the administration mark' and of relationship promoting as hazard reducers, simplifiers of decision and underwriters of value. Davis explored showcasing connections in the foundation and on-going administration of an on-line store activity, and arrived at comparable 
ends to Riley and de Chernatony. Little researched the procedures of client esteem creation and conveyance from an association wide point of view. The calculated structure that rose portrayed client esteem creation and conveyance as a set of three of procedures: making, keeping and empowering guarantees, reliable with the three guarantees system. An essential fourth measurement likewise developed: the 'acknowledgment' of the esteem made by these three procedures, recognizing the yields of interest in promoting forms as an incentive for clients, and money related an incentive for the firm. In this manner it is suggestive that the thought of client esteem acknowledgment is firmly connected to the job of the administration mark.

Glynn and Brodie concentrated on understanding the job of marking in the more extensive showcasing framework, by exploring how marks make an incentive in manufacturer-affiliate connections. The examination was propelled by Webster, who attracted consideration regarding the imperative job that brands play in channel connections. The exploration uncovered those producers' brands given three wellsprings of significant worth to affiliates: non-budgetary advantages (e.g. promoting backing and item classification development), client mark value, and advantages for the affiliate's clients. Like the discoveries of Davis and Riley and de Chernatony the exploration uncovered that brands go about as 'facilitators of relations' in channels, making significance and experience for affiliates. The result is expanded affiliate fulfillment with the administration mark, upgraded execution view of the administration mark, pledge to the administration brand, and trust in the producer [50].

\section{Benefits brand identity brings to restaurants}

One benefit of branding is that it builds up sales through customer brand loyalty. Berry [50], believes that a brand increases customer trust for the brand and it enables them to visualize and comprehend the otherwise intangibles of products or services. Another advantage of a strong brand is that it has reduced costs, as a result of scale economies in marketing spend. According to Holverson and Revaz, the following are some benefits of branding to the company:

Clear recognition by customers: As a result of the existence of many producers of the same products and offering the same services, with little time to choose, branding helps customers to know which products offer which features and functions and that makes choosing much easier.

Management and employees are trained to live the brand: Management and employees of all organizations are its brand ambassadors. This is because they interact with the customers and sell them the product or service. To be able to effectively sell the brand to customers, they need to live the brand. It helps grow the value of the company: The actual value of the brand lies with its customer base and the recognition of the brand. For example, for a power brand, people are willing to pay two or three times more the store price for that product. The brand of a company, thus, drives its revenues and profits. Further, time is also a great zonal arena to consider when dealing with people in as much as restaurants operation is concerned.

As [20] showed, on the off chance that you infuse time as an antitoxin in your everyday dealings, you will dependably have sound minutes cum productive outcomes. Along these lines, time should be clung to in as much as an efficient restaurant is in activity.

Basically, a brand is gainful to both the organization and the client in different ways. The significance of marking to the organization can't be downplayed in light of the fact that it makes an incentive for either its items or administrations and furthermore its clients all things considered specialist co-ops should be client arranged towards giving fulfilling administrations to their clients.

\section{Methodology}

The study covers the research design, population, sampling size and sampling techniques, data collection, cum research instrument and data analysis. Regarding the sampling techniques utilized, the researchers used a sample size of forty five (45). Fifteen of the sample sizes were made of the staff of the restaurant and thirty were customers. The customers were selected using simple random sampling technique. However, non-probability sampling (purposive sampling) technique in sampling out the staff of the restaurant was utilized. This was adopted because; according to Procter \& Allen the technique helps to obtain rich sources of data. Furtherance to Procter and Allen's opinion, it helps the researcher(s) to intentionally select who to include in the study on the basis that those selected can present the requisite data Parahoo. The study used both primary and secondary data for this work. The primary data for the study were obtained from the views of respondents expressed in the questionnaire and in the interview. These comprise of scholarly journals (through the internet and available hard copies), research reports, educational guides, library research, textbooks, etc. relating to promotion together with fresh information.

\section{Data Analysis/Results}

\section{Objective one- level of awareness of brand identity among customer}

Table 2 results revealed level of awareness of component of brand identity among the restaurant customers. That majority of customers of the restaurant are not aware about the brand identity for restaurants. Table 2 indicates that, fifteen (15) respondents representing fifty per cent $(50.0 \%)$ of customers are not unaware of the brand identity of restaurants. However, eight (8) of the respondents representing twentyseven per cent $(27 \%)$ indicated the awareness of the brand identity of restaurants. The remaining seven (7) of the respondents representing twenty-three per cent $(23 \%)$ were undecided and or neutral about the brand identity of restaurants. The marketing implications are that operators of these restaurants in Accra Business Centre need to do a lot of promotion so as sensitize customers on their brand. Maybe there will be the need for rebranding so as to attract more customers and subsequently enjoy the benefits thereof. The result on the other variables however showed that most the customers are not satisfied with the performance of the restaurant operators. This is evident in their neutrality/indecisiveness on the variables. The customers overall expectations were not fulfilled within this dimension. The researchers are of the view that the restaurant operators be trained and educated more on brand identity, service standards and customer relationships [51].

\begin{tabular}{|c|c|c|}
\hline Responses & Frequencies (45) & Percentages (100) \\
\hline Aware & 8 & 27 \\
\hline Unaware & 15 & 50 \\
\hline Undecided & 7 & 23 \\
\hline Total & 30 & 100 \\
\hline
\end{tabular}

Table 2: Level of awareness of brand identity among customers. 


\section{Objective two-influence brand identity has on customers' choice of local restaurant}

In consideration of objective two, eight of the respondents representing $27 \%$ of the customer who indicated their awareness of brand identity of restaurants, these were the responses given as to how brand identity influence their choice of local restaurants. According to the respondents the brand of a local restaurant makes them to be loyal to the local restaurant they prefer hence always choosing that restaurant over others. Hence the brand serves as a magnetic pull that draws them (customers) to the local restaurant. Additionally the customers indicated that they become empathetic towards the restaurant and its brand. As indicated by Zeithaml, Berry and compassion is about simple access, great correspondence and understanding the client. Portrays those components independently . Simple access is associated with the congeniality which implies for instance if the working hours are helpful, the areas of the offices are advantageous, and the holding up times are short. Great correspondence is tied in with keeping the client educated in a dialect they can comprehend and furthermore tune in to the client. The organization may need to make a few changes with a specific end goal to incorporate remote clients to belittle neighbourhood dishes for the earth must be perfect and appealing that impact item or administration decisions. Understanding the client is tied in with attempting to comprehend the client which includes finding out about particular necessities, giving individualized consideration and perceiving additionally the general client. The second explanation expressed by the respondents on how brand identity influences their choice of a local restaurant is that the brand influences their behaviour when they get to the ambiance of the restaurant. Thirdly the brand makes them loyal to the restaurant. Hence even when situations are not good for the restaurant they still stick to the restaurants. These opinions made on the by the customers is in synch with that of Brakus.

\section{Objective three-ascertaining if the brand identity adopted by local restaurants meets standard components}

In order to obtain adequate information on whether respondents were aware if adopted brand identities meet standard identities, the total of thirty respondents' response was used. The thirty is made up of the 8 (who had indicated their awareness of the brand), 7 (who had expressed neutrality of awareness knowledge and 15(all staff of Odorice). Below are the dynamics of the responses of the thirty respondents (Figure 3). Fifteen (15) of the respondents representing $50.0 \%$ indicated that the brand identities of local restaurants do not meet standard operation measure whiles Nine (9) of the respondents representing $30 \%$ responded in the affirmative. The remaining six (6) of the respondents representing $20 \%$ were however neutral. In all the marketing implications are that majority of the customer group identified in this study were not satisfied about the level of brand identities and service standard requirements offered by the restaurant operators. Restaurants must pay great attention towards

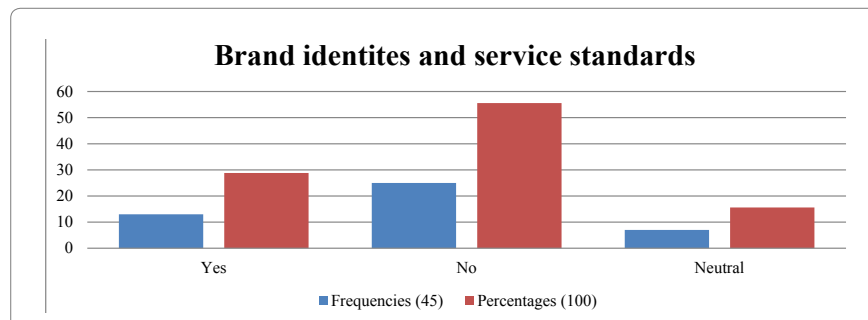

Figure 3: Brand identities and service standard investing considerable amount and time on provision of better quality services to their consumers in order to survive and compete in the long run. The researchers therefore compared the various variables under the SERVQUAL dimensions including tangibles, reliability, responsiveness, assurance and empathy.

Kruskall-Wallis-test non-parametric analysis was further conducted to test on the SERVQUAL variables among customer group identified where RES \& CUST represent (restaurant operators 1 to 3 and Customers) respectively. The test revealed statistically significant difference across the groups. The set of variables tested and the mean and median marks were included. From the above, the values obtained when tested $(\mathrm{Mdn}=3.342)$ being the highest and $\mathrm{z}$-values within the range of (2.017-3.275) with the p-values of ( 0.000 to 0.002$)$ showing the significance of the tested variables when compared to the cut of means and $p=0.05$. It was found that Tangibles, Reliability, Responsiveness, Assurance, Empathy as some of the impact on brand equity in restaurant operation business.

However a pair wise tested conducted among the respondents revealed that Customers rated higher "Reliability" ( $\mathrm{Mdn}=3.342$, $\mathrm{z}=3.023, \mathrm{p}=0.00)$; "Responsiveness" $(\mathrm{Mdn}=3.341, \mathrm{Z}=3.302, \mathrm{P}=0.003)$; "Assurance" ( $\mathrm{Mdn}=3.411, \mathrm{Z}=2.578, \mathrm{P}=0.000)$; compared to "Tangibles" $(\mathrm{Mdn}=3.132, \mathrm{Z}=3.017, \mathrm{P}=0.000)$ and "Empathy" $(\mathrm{Mdn}=3.304, \mathrm{Z}=3.223$, $\mathrm{Z}=0.002)$; among the restaurant operators. The implications are that service quality is influence by the evaluation of customer's perception of elements such as interaction quality, physical environment quality, and outcome quality. These elements are in turn evaluated based on specific service quality dimensions; reliability, assurance, responsiveness, empathy and tangibles. Thus; the results showed that customers agreed more on the elements analysed under each variable in this order, i.e. tangibles first, followed by responsiveness, reliability, assurance and empathy in that order. A high rate of customers under consideration however indicates that serious attention ought to be given to such variables. This result show that the customers were not satisfied with the quality in terms of responsiveness, and assurance for instance described under the various dimension and were not aware of what those variables stand for.

Also, quite a number of respondents disagreed on most of the variables/elements in question. The researchers felt that the rate of disagreement should have been lower than the current percentages recorded. This is because for an element such as empathy which dealt on communication and understanding of customers, caring for customers should have been well exhibited by the employees of the hotel towards enhancing customer loyalty. The results on customer's strong disagreement on some of the variables/elements were not much to have impacted on the hotels performance in the various variables/ elements. According to Parasuraman (1990) tangibles are about physical facilities, equipment, personnel and communication material. This dimension includes physical facilities, equipment, personnel and communication material and if the personnel appear neat.

The results showed that the tangible aspect of the hotel on offering attractive menu has met the expectation of the customers more as compared with the other variables. Also the dinning area's comfort ability and cleanliness, conference room's arrangement and cleanliness, bedrooms cleanliness and comfort ability of beds and neatness of the bedspreads were agreed on to have satisfied their expectations. There was a strong agreement on the availability of parking space at the indigenous restaurants in Accra Business Centre. This feature is very visible and true. 
Most customers however are neutral/undecided on the elements analysed under the various variables. This result show that the customers are not either satisfied with the quality described in this dimension or that they have not experienced those services before. The researchers are of the view that the findings are confirmations of the models and theories of Parasuraman, Dobree and Gronroos. Further, the reliability is connected to the consistency of performance and dependability, Grönroos. This dimension includes keeping promises, showing a sincere interest in solving problem, give right service the first time, providing the service at the time the company promise to do so and trying to keep an error free record. That means that this dimension can be connected to both technical quality and functional quality. Showing a sincere interest in solving problems is about the manner in which the service is delivered and therefore it is connected to the functional quality. Furthermore, Table 3 result showed that the customers were not fully satisfied with the quality described in this dimension. This is very evident from the results and this dimension has not fully confirmed the findings in the models. According to Grönroos, Responsiveness is concerned with the extent to which the employees are prepared to provide service. This involves factors such as mailing a transaction slip immediately, calling a customer back in short time and giving prompt service.

This measurement addressed subjects as data about the administration, giving brief administration, representative's readiness to encourage the clients and that the workers never are excessively caught up with, making it impossible to react to demands from clients. This measurement can be associated with the specialized quality on the grounds that the highlights are about how the administration is conveyed. The clients don't feel that their general desires are satisfied inside this measurement. This outcome demonstrated that the clients are not in the slightest degree happy with the quality depicted in this measurement. This variable has not gotten great reaction from the respondents. Aside from the perfect appearance of workers and staff and their neighbourliness towards clients, every other variable were not sufficiently acceptable. The researchers are of the view that this score came because of client's absence of information on the majority of the components or factors. For instance, clients who have not had room reservation administrations, visited the gathering lobby for gatherings or have not invested quality energy at the inn probably won't know a lot of a large portion of the components/factors being referred to. The clients don't imagine that their general desires are satisfied inside this measurement.

As per Zeithaml, Berry and Parasuraman affirmation is about capability, kindness, validity, and security. Grönroos [6] depicts those elements independently; kindness is about good manners, regard, thought, benevolence of contact staff (counting receptionists, phone administrators et cetera). Ability is associated with the information and aptitudes of contact staff, operational help work force (and furthermore explore capacity) that are required for conveying the administration. Validity includes factors, for example, dependability, credibility and genuineness. It intends to the level the organization has the client's best enthusiasm on the most fundamental level. Variables that influence the validity are the organization's name, notoriety, individual qualities and how much is associated with cooperation with clients. Security implies opportunity from threat, hazard or uncertainty. Elements included are: physical wellbeing, money related security and classification. This measurement can likewise be associated with the useful quality [6]. This measurement is about the conduct and capacity of the representatives to impart certainty, secure exchanges, and kindness of the workers and the information of the representatives to answer inquiries from clients.

\section{Objective four-finding out how brand identity benefits the local restaurants}

The respondents indicated that brand identity among other benefits, brand identity restaurant operational profit; restaurants also enjoy repeated purchase by their customers who are fond of their brand. Concurrently customer(s) empathize(s) with the brand of the local restaurant. Furtherance to increase in sale of restaurants, there is the increase in market share by the local restaurant. The various percentages in terms of the various benefits are as captured in Figure 4.

\section{Summary of Findings, Conclusion \& Recommendations \\ Summary findings}

Based on the set objectives of the study, the following finds were made and summarized accordingly. It was observed from the studies that, 50 per cent of respondents were not aware of the brand identity that local restaurants should portray whiles only 27 percent of the respondents were aware. According to the respondents, the brand of a local restaurant makes them to be loyal to the local restaurant they prefer hence always choosing that restaurant over others. Additionally, the customers indicated that they become empathetic towards the restaurant and its brand. Again the, explanation expressed by the respondents on how brand identity influence their choice of a local restaurant is that the brand influences their behaviour when they get to the ambiance of the restaurant. Thirdly the brand makes them loyal to the restaurant. Hence even when situations are not good for the restaurant they still stick to the restaurants. These opinions made by the customers are in synch with that of Brakus. It was also observed that 50.0 per cent of the respondents indicated that the brand identities of local restaurants do not meet standard operation measure whiles Nine (9) of the respondents representing 30\% responded in the affirmative. Finally it was revealed that brand identity enhances restaurant operational profit; induces repeated purchase by customers fond of their brand. Concurrently draws in empathy from customers and ultimate increase in market share by the local restaurant(s).

\begin{tabular}{|l|c|c|c|c|c|c|c|c|}
\hline \multirow{2}{*}{ Statements } & RES1 & RES2 & RES3 & RES3 & CUST & Z-values & P-values \\
\hline $\mathbf{1}$ & Tangibles & 3.132 & 2.153 & 2.223 & 2.014 & 2.101 & 3.017 & 0.000 \\
\hline $\mathbf{2}$ & Reliability & 2.221 & 3.112 & 2.002 & 1.745 & 3.342 & 3.023 & 0.002 \\
\hline $\mathbf{3}$ & Responsiveness & 3.286 & 3.042 & 3.311 & 2.223 & 3.341 & 3.302 & 0.003 \\
\hline $\mathbf{4}$ & Assurance & 3.221 & 3.012 & 2.017 & 2.077 & 3.411 & 2.578 & 0.000 \\
\hline $\mathbf{5}$ & Empathy & 3.175 & 3.017 & 3.012 & 3.304 & 2.079 & 3.223 & 0.002 \\
\hline
\end{tabular}

* Correlation is significant at the 0.05 level (2-tailed). Source: field survey 2018, 5 strongly agree 1 -strongly disagree

Table 3: Kruskal-wallis test on the components of brand identity

How brand identity benefit local restaurants

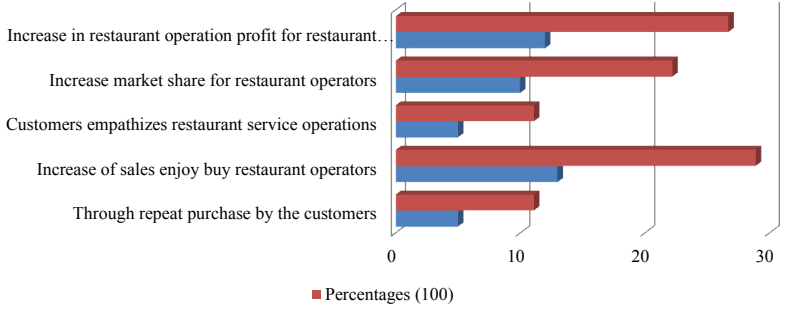

Figure 4: Influence of brand identity. 
Citation: Selase AE, Abdoulaye AM, Mawuli MD, Brantson TE (2018) The Identity of Brand with its Influenceable Character on Client Choices of Predominant Restaurants Accra as the Lens. J Account Mark 7: 302. doi: 10.4172/2168-9601.1000302

Page 11 of 12

\section{Conclusion}

It was found from the study that level of awareness of component of brand identity among the restaurant operators and their customers was very low and that brand identity influence customers choice of local restaurant. It therefore means that to ensure repeat purchase by the customers, increase of sales enjoyed by restaurant operators, increase in market share and operational profit etc. it is critical the local restaurant engage in drive marketing activities to promote their brand and to stay in business.

\section{Recommendations}

The researchers recommend that the following be done towards improving the indigenous restaurant operators in Accra Business Centre image and service quality towards meeting customer's expectation.

Educate/train both management and employees on brand equity: There is the need to provide both the management and employees of local restaurants the requisite skill in good branding practices and how to render quality service to customers. Employees should be trained on customer service practices in order to make them competitive and knowledgeable on the job.

Finding creative ways of communicating the brand and Service standards: Local restaurants are encouraged to find more ingenious ways of communicating their brand to customer's that does not involve spending so much money. To create awareness and increase patronage, they could invite their key customers as brand ambassadors to try out their services for free. If the service is good, the brand would be communicated via word of mouth referrals. They should make publications about the restaurants online or in popular newspapers and magazines. Additionally, the indigenous restaurant operators in Accra Business Centre could leverage on secondary associations with corporate institutions such as universities, banks, insurance companies, etc. to create awareness about their brands.

Motivating staff/employees: The indigenous restaurant operators in Accra Business Centre could implement a standard remuneration package for employees towards motivating them better. The remuneration packages should, however be very good so that this strategy does not result in disgruntled employees. When the employees are well motivated, they would facilitate the better branding and service delivery of the restaurants beyond expectations. This could be done through bonuses, special packages, allowances on transportation, health care, and not necessarily in a form of cash or material things but motivating people in general can also be in a form of a pep talk.

\section{Limitations of the Study}

There are a handful of limitations encountered in this research that deserve acknowledgement. Due to limited resources the study was conducted only on Accra metropolis. Time constraints and finance combined constituted other major constrains to the research. The researcher's would have taken other categories of restaurants and hotel operating in the region and across the length and breadth of the country to conduct comparative analysis across diverse star classifications for universalism. (Suggested for future research) Another limitation of this research was the smaller sample size.

\section{References}

1. Berry LL, Zeithaml VA, Parasuraman A (1990) Five imperatives for improving service quality. Sloan Management Review 31: 9-38.
2. Aaker D, Allan DS (1991) Managing Brand Equity. New York: The Free Press 30: 256.

3. Aaker DA, Shansby JG (1982) Positioning Your Product. Business Horizons 25: $56-62$

4. Aaker DA (1996a) Building Strong Brands, New York, the Free Press/Simon and Schuster.

5. Aaker DA (1996b) Measuring Brand Equity across Products and Markets California Management Review 38: 102-120.

6. Aaker DA, Joachimsthaler E (2000) Brand Leadership New York. The Free Press.

7. de Chernatony L, Segal-Horn S (2003) "The criteria for successful services brands", Eur J Mark Pp: 1095-1118.

8. Aaker DA, Kumar V, Day G (2004a) Marketing Research New York, Wiley.

9. Aaker JL (1995) Measuring the Human Characteristics of a Brand: A Personality Hierarchy Advances in Consumer Research 22: 391-395.

10. Abratt R (1989) A New Approach To The Corporate Image Management Process. Journal of Marketing Management 15: 63-76.

11. Aaker JL (1999) The Malleable Self: The Role of Self-Expression in Persuasion. J M Res 36: 45-57.

12. Adams GB, White JD (1994) Dissertation Research in Public Administration and Cognate Fields: An Assessment of Methods and Quality. Public Administration Review 54: 565-576.

13. Aaker JL, Fournier S (2004b) When Good Brands Do Bad. J Consum Res 31: 1-16.

14. de Chernatony L, Harris F, McDonald MHB (2001) "Corporate marketing and service brands-Moving beyond the fast-moving consumer goods model", Eur $\mathrm{J}$ Marketing 35: 335-352.

15. Aaker JL (1997) Dimensions of Brand Personality. J M Res 34: 347-356.

16. Grönroos C (1994) From Marketing Mix to Relationship Marketing: Towards a Paradigm Shift in Marketing. Management Decision 32: 4-20.

17. Agarwal P (2004) The Effects of Brand Relationship Norms on Consumer Attitudes and Behavior. J Consum Res 31: 87-101.

18. Agarwal P, Roa V (1996) An Empirical Comparison of Consumer-Based Measures of Brand Equity. Marketing Letters 7: 237-247.

19. Aitken R, Ballantyne D, Osborne P, Williams J (2006) Introduction to the specia issue on the service-dominant logic of marketing: insights from The Otago Forum. Marketing Theory 6: 275-280.

20. Aphu E S (2018) The Impact of Recruitment and Selection Criteria on Organizational Performance. GN Bank, Greater Accra Region of Ghana as the Mirror. J Public Administration and Governance 8: 283.

21. Appiah AK, Fyall A, Singh S (2000) Marketing Culture and Customer Retention in the Tourism Industry. The Service Industries Journal 20: 95-113.

22. Argenti PA, Druckenmiller B (2004) Reputation and the Corporate Brand Corporate Reputation Review 6: 368-374.

23. Azoulay A, Kapferer JN (2003) Do Brand Personality Scales Really Measure Brand Personality? Journal of Brand Management 11: 143-155.

24. American Marketing Association (1960) Marketing Definitions: A Glossary of Marketing terms.

25. Aphu ES, Xing C (2015) The Study of Time Management in Civil Service Institutions in Ghana: A Case of Accra Metropolitan Assembly. Eur J Business and Management 7.

26. Baker WE, Sinkula JM (1999) The Synergistic Effect of Market Orientation and Learning Orientation on Organizational Performance. Academy of Marketing Science 27: 411-427.

27. Baker WE, Sinkula JM (2005a) Environmental Marketing Strategy and Firm Performance: Effects on New Product Performance and Market Share. J the Academy of Marketing Sci 33: 461-475.

28. Baker WE, Sinkula JM (2005b) Market Orientation and the New Product Paradox. The Journal of Product Innovation Management 22: 483-502. 
Citation: Selase AE, Abdoulaye AM, Mawuli MD, Brantson TE (2018) The Identity of Brand with its Influenceable Character on Client Choices of Predominant Restaurants Accra as the Lens. J Account Mark 7: 302. doi: 10.4172/2168-9601.1000302

29. Ballantyne S, Varey R J (2008) The Service-Dominant Logic and the Future of Marketing. Journal of the Academy of Marketing Sci 36: 11-14.

30. Balmer JMT (1998) Corporate Identity and the Advent of Corporate Marketing. Journal of Marketing Management 14: 993-996.

31. Balmer JMT (2001a) Corporate Identity, Corporate Branding and Corporate Marketing-Seeing Through The Fog. Eur J Marketing 35: 248291.

32. Balmer JMT, Greyser S (2003) Revealing the Corporation. Perspectives on Identity, Image, Reputation, Corporate Branding and Corporate Leve Marketing, London Routledge.

33. Balmer JMT, Greyser SA (2006) Corporate Marketing: Integrating Corporate Identity, Corporate Branding, Corporate Communications, Corporate Image and Corporate Reputation. EurJ of Marketing 40: 730-741.

34. Barney JB (1991) Firm Resources and the Theory of Competitive Advantage Journal of Management, Considerations. Journal of Personality and Social Psychology 51: 1173-1182.

35. Baumgarter H, Steenkamp JB, (2001) Response Styles in Marketing Research: A Cross National Investigation. Journal of Marketing Research 38: 143-156.

36. Becker B, Gerhart B (1996) The Impact of Human Resource Management on Organizational Performance: Progress and prospects. Academy of Management Journal 39: 779-801.

37. Berry LL (1980) Service Marketing Is Different. Business 30: 24-29.

38. Berry LL (2000) "Cultivating Service Brand Equity". Journal of the Academy of Marketing Science 28: 128-137.

39. Blackwell R, Blackwell K (2001) Creating Consumer-Driven Demand Chains in food Service. Journal of Restaurant \& Foodservice Marketing 4: 137-154.

40. Brakus JJ, Schimitt HB, Zarantonello L (2009) Brand Experience:What is it? How is measured? Does it affect loyalty?
41. Carman JM (1990) Consumer perceptions of service quality: an assessment of the SERVQUAL dimensions. Journal of Retailing 66: 33-35.

42. Chen C, Ting S (2002) A study using the gray system theory to evaluate the importance of various service quality factors. The Inter J Quality \& Reliability Management 19: 838-861.

43. Clifton R, Simmons J (2003) "Brands and branding", The Economist, Great Britain, Pp: 13-25.

44. Cowell DW (1984) The marketing of services, 1st edition, journal of business logistics.

45. de Chernatony L, Dall'Olmo Riley F (1999) "Experts' views about defining services brands and the principles of services branding", J Business Res 46 : 181-192.

46. Fu YY, Parks SC (2001) The Relationship between restaurant service quality and consumer loyalty among the elderly. J Hospitality and Tourism Research 25: $320-336$.

47. Gale BT (1992) Quality comes first when hatching power brands. Planning Review 20: 7.

48. Gummesson E (1993) Making Relationship Marketing Operational. Making RM Operational 5: 5-20.

49. Gummesson E (2002) Total Relationship Marketing-Marketing Management, Relationship Strategy and CRM Approaches for the Network Economy.

50. Kapferer JN (2008) The New Strategic Brand Management-Creating and sustaining brand equity long term. Business \& Economics p: 560 .

51. Prasad K, Dev C (2000) Measuring hotel brand equity: A customer-centric frame work for assessing performance," 41: 22-31. 